Vol. 1, nº1 | 1997

Varia

\title{
« Harmful tramps » Police professionalization and gypsies in Germany, 1700-1945
}

\section{Leo Lucassen}

\section{OpenEdition}

\section{Journals}

Electronic version

URL: http://journals.openedition.org/chs/1029

DOI: $10.4000 /$ chs. 1029

ISSN: 1663-4837

Publisher

Librairie Droz

\section{Printed version}

Date of publication: 1 January 1997

Number of pages: $29-50$

ISSN: 1422-0857

\section{Electronic reference}

Leo Lucassen, « « Harmful tramps » Police professionalization and gypsies in Germany, 1700-1945 », Crime, Histoire \& Sociétés / Crime, History \& Societies [Online], Vol. 1, n | 1997, Online since 03 April 2009, connection on 30 April 2019. URL : http://journals.openedition.org/chs/1029; DOI : 10.4000/ chs. 1029 


\title{
«Harmful tramps» \\ Police professionalization and gypsies in Germany, 1700-1945'
}

\author{
Leo Lucassen
}

\section{INTRODUCTION}

uring the last decade the history of gypsies in Germany has reached a stage of maturity. Several studies have been published which give important insights into the way in which German authorities have dealt with people they categorize as 'Zigeuner'" . Despite this coming of age, there are three aspects which still demand further elaboration and deeper consideration. First of all, while some also cover the preceding Empire and Weimar era, most studies concentrate on the Naziperiod (1933-1945). For a full understanding of the anti-gypsy policy of German authorities in the twentieth century, a much longer time-span should be covered. Especially the decades preceding the German unification, about which the information we have is only very scanty ${ }^{3}$, should be analysed much more thoroughly.

A second shortcoming in the German historiography is its failure to problematize the way travelling people have been categorized and labelled throughout time by authorities, especially by the police. Instead, almost all authors start from the assumption that the people subsumed under this label form a homogeneous ethnic group. The labelling is thus supposed to conform to the self-definition of the people concerned. As I have argued elsewhere, this assumption does not hold water when put to the test. Not only in Germany, but also in the Netherlands ${ }^{4}$, the definition of who was to be considered a gypsy has shifted considerably over time, and at the same time, it is not at all clear whether the people thus labelled shared a common ethnic identity ${ }^{5}$.

A third and final weak spot is the isolated approach with which the gypsy theme has been explored by German historians. Especially the link with other fields, which are important to achieve a satisfactory explanation for the discrimination against and persecution of gypsies, are made only sporadically and not very systematically. As a result gypsy studies have only rarely been incorporated into more general German history ${ }^{6}$.

1 This article is a revised version of the paper presented at the Annual Meeting and conference on Gypsy Studies (Leiden, May 29-31 1995). It is based mainly on my recent book (Lucassen, 1996). The research was made possible by a fellowship of the Royal Netherlands Academy of Arts and Sciences.

2 The most important studies are mentioned throughout this paper. I also refer to my historiographical overview (Lucassen, 1995).

3 A notable exception is Fricke (1991).

4 Lucassen (1990).

5 Lucassen (1995).

6 An exception is the work of Burleigh and Wippermann (1991) and to a certain extent Ayass i.a. (1988). 
This lack of a more general incorporation is thrown into especially sharp relief in the recently booming field of police history ${ }^{7}$. The link with this specialization is relevant, because it was the police who were primarily responsible for labelling travelling people gypsies. In this paper, I therefore want to elaborate on the problem of labelling in relation to the professionalization of the police.

Although police historians have focused on the same periods as their colleagues in the gypsy field ${ }^{8}$, I will not restrict myself only to the period from 1870 onwards. The reason being that there are many indications that the process of labelling by the police had already started in the eighteenth century. In this sense, this paper will also deal with what we could perhaps call the 'proto-history' of the police in the period preceding the unification of Germany. There are some studies about the activities of the political police and the burgeoning labour movement $(1848 !)^{9}$, but these pay little attention to the more day-to-day police practices involved in the surveillance of 'dangerous' or 'suspicious' persons.

Among the barely used sources which shed a tremendous amount of light on this matter are the numerous police journals (Polizeiblätter) which were issued in most German states. These journals, which began to be widespread about 1830 , were preceded by more or less private publications in the form of printed warrants (Steckbriefe) compiled by more highly placed policemen, who gained themselves a reputation as Kriminalisten, people specialized in the fight against organised crime.

Both sources contain numerous descriptions of persons who for various reasons were wanted by the police. The reasons vary from murder and robbery to not having the requisite licences to exercise itinerant professions, insulting civil servants or 'disorderly behaviour'. When these sources are analyzed three things strike the eye. First of all, most people are harried because of their apparently aimless itinerant lifestyle, characterized as Umherzieher. As Elaine Glovka Spencer justly noted about the Düsseldorf police around 1850:

Where industry had not yet made major inroads, vagabonds and beggars - anyone without a fixed residence and a readily identifiable source of income - remained the foremost focus of concern ${ }^{10}$.

Secondly, in the course of the nineteenth century, especially after 1840 , there was a growing tendency to label some of them gypsies (Zigeuner). Finally, the very existence of warrants, police journals, and Kriminalisten from the eighteenth century draws our attention to the fact that even before the specialization of the police in Germany in the last decades of the nineteenth century, important developments had been taking place. In this respect I propose to broaden the concept of 'professionalization' somewhat and not restrict it to the process of 'academization', which is the way it is mostly interpreted in the German literature ${ }^{11}$. My aim is also to include those activities which were directed towards the improvement of police methods.

This approach enables us to get a better insight in the proto-history of the police and at the same time to trace the tradition of gypsy-labelling. More specifically, in

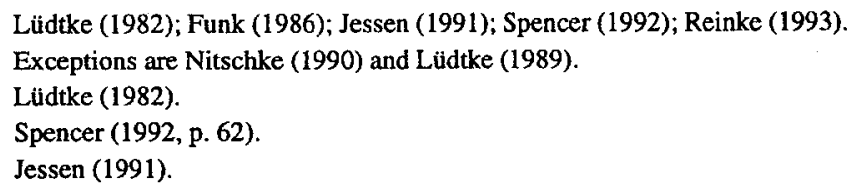


this paper I will try to discover whether there is a connection between the activities of the Kriminalisten and the persecution and stigmatization of gypsies and other travellers by the nazis. This question is especially relevant, as there is a huge body of literature on this matter ${ }^{12}$, which - in my opinion - tends to overlook the long-enduring tradition of police behaviour, not only towards gypsies, but also with respect to 'harmful tramps' in general. Finally, I will go into the question of to what extent the gypsy-identity was forged and stimulated by the long tradition of stigmatization and labelling.

\section{THE ISSUING OF WARRANTS AND THE FIRST KRIMINALISTEN (1700-1830)}

In the eighteenth century the police in the modern sense of the word was virtually non-existent. Only a few people were responsible for detecting criminals, the power of the state being curtailed by intermediary bodies such as the nobility, the church, and cities ${ }^{13}$. This does not imply that criminals and bands of robbers were left in peace. Through the interrogation of suspects and the exchange of information with other civil servants, the attempts of local officials seemed to have been more successful than is often assumed. An important method of laying a felon by his heels was the composition and distribution of warrants ${ }^{14}$ : list of names, professions, and descriptions of persons who were suspected of crimes, derived mostly from the interrogation of captured thieves, burglars, or vagrants.

The most remarkable aspect of these Steckbriefe, which differ enormously in quality, is the great number of petty thieves and con-men, beggars and vagrants. A mere itinerant lifestyle could be sufficient to be deemed dangerous and consequently to be considered a potential criminal. In Germany this broad category was labelled Gauner (bandits) or Vaganten (vagrants) and in some cases Zigeuner.

Although there are several examples of high quality lists containing warrants from the first half of the eighteenth century, after roughly 1750 the Steckbriefe became more elaborate, systematic, and bulky ${ }^{15}$. This is also the period in which a number of civil servants charged with police-work tried to improve the tracing of criminals and pointedly stressed their identity as Kriminalisten. The initiator was the Württembergian Oberamtmann Georg Jakob Schäffer, characterized by Bader as «Monomanen der Jaunerbekämpfung» ${ }^{16}$ - who can be considered the first Kriminalist. In the service of the duke of Württemberg he was an outstanding example of the eighteenth century enlightened civil servant who wanted to escape the geographical and social boundaries fixed by the society of estates. Although in practice "indirect rule' still dominated the administration of European states, his aims were to create a unitary police system that would cross the borders of his own principality and unite the efforts of judicial authorities in other South German and Swiss states as well.

12 For a critical overview see Lucassen (1995) and Willems (1995).

13 Nitschke (1990, p. 190-193).

14 Danker (1988, p. 444-445): «Seit dem frühen 18. Jahrhundert institutionalisierten eifrige Kriminalisten diese gezielten, grenzübergreifenden Fahndungsansätze durch die Anfertigung von Gaunerlisten» (p. 445). See also Dubler (1970, p. 49-50).

16 Bader (1962, p. 303). 
Encouraged by his activities, the tracing of criminals by way of Steckbriefe and co-operation with colleagues in other states was greatly stimulated. Schäfffer's meticulous descriptions and the wide distribution of his lists were examples followed by others. One of his imitators was Franz Ludwig Schenk von Kastell, nicknamed Malefizschenk, who published the extensive Oberdischinger Liste in 1799. He made use of Schäffer's lists and produced some 1487 descriptions of the Jauner und Bettel Gesindel. Among other names which spring to mind is that of Friedrich August Roth from Baden who published an even longer list with 3147 names a year later ${ }^{17}$. The fourth dedicated Kriminalist was Friedrich Freiherr von HundbissWaltrams, who also hailed from Baden. He maintained close contact with the other criminalists and in 1804 gave an account of his detective work in a modest but qualitatively good Jaunerlist.

The most important aspect of these lists was the professional co-operation between the compilers, which transcended the local or regional significance of previous Steckbriefe. All were influenced by the Enlightenment and the ideology of the central state, which was stimulated by the Reichsdeputationshauptschlu $\beta$ of 1803 (when dozens of small states, especially in the southern part of Germany disappeared) ${ }^{18}$. They tried to achieve a good insight into what they saw as the criminal underworld, with the ultimate aim of making its denizens useful citizens.

During the first decades of the nineteenth century, the initiative started by the first criminalists was taken over by others who published their results in so called Aktenmäßige Nachrichten. Written predominantly for (judicial) colleagues ${ }^{19}$. As we mentioned earlier, the activities of the criminalists have to be seen in the light of the process of state formation which gained momentum during the Napoleonic period and which was superseded by a direct form of government ${ }^{20}$. A more rational and effective «war on crime» fits in nicely in this general development. Many criminalists also saw a direct relationship between the fight against criminality and a thorough reform of the system of government ${ }^{21}$.

It has to be said, that the criminalists were ahead of their contemporaries. Quite a lot of water would flow under the bridge before the German states realized the consequences of the new approach. Schäffer, for example, had great trouble financing the publication of his lists and others had to sell their Aktenmäßige Nachrichten in order to pay for the printing costs. Another hindrance was that, until the second half of the nineteenth century, there was virtually no police personnel to put the recommendations of the criminalists into practice.

\section{THE CONSEQUENCES OF THE 'GYPSY-LABELING»}

In what respect did this general development within the police force stimulate the labelling of travelling people as gypsies? The answer in a nutshell is, not very much.

\footnotetext{
17 See also Bader (1962 p. 296).

18 To the benefit of Württemberg and Baden.

19 Danker (1988, p. 463). In Stuhlmüller's introduction (1823), he states that his book is meant only for the police and the courts and «not at all for the bookshops». The only ones to explicitly adress «the public» were Pfister and Falkenberg.

20 Tilly (1990).

21 Finzsch $(1987$, p. 450$)$.
} 
In most Steckbriefe or Aktenmäßige Nachrichten gypsies did not play an important, let alone dominant, role. Far more widely used were labels Gauner, Jauner and Umherzieher, and in some cases «Jewish bandits». The only exception to this rule was Schäffer, whose reputation was to a certain extent established by his Zigeunerliste of $1787 / 1788$. The main motive behind this was the trial of a gypsy bandit named Jakob Reinhardt, better known as Hannickel, but this stimulated the sensitivity towards «gypsies» only temporarily, so that after 1800 the interest in this group quickly waned $\mathrm{d}^{22}$. The decline in the stigmatization of gypsies was probably closely linked to the ideology of the Enlightenment and the efforts made in various German states to integrate gypsies. An initial impulse can be found in Schäffer's 1788 list:

Möchte doch, (dann das würde wohl das beste Hülfs-Mittel sein) jeder teutsche Reichsfürst in denen Ihme anvertrauten Staaten ein besonders vor Zigeuner, Jauner und Vaganten aller Art bestimmtes Arbeitshaus gnädigst errichten lassen, alles herumziehende Gesindel in dasselbe ohne Nachsicht verweisen [...] Gewis, sie würden den auch unter dem Tros der Menschheit oft noch verborgenen guten Funken wieder anblasen, sie zu bessern brauchbaren Gliedern der MenschenFamilie umbilden, und auf diese Weise Landes Ruhe und Sicherheit, und Menschen-Wohl um sich her verbreiten! $!^{23}$.

He repeated this call in his last Jaunerbeschreibung published in 1813, one year before his death, in which he referred to the popular and widely read book on gypsies by Grellmann ${ }^{24}$. Between 1820 and 1840 in Württemberg and Prussia (Friedrichslohra) authorities did indeed establish «colonies» for gypsies and tried to allow them the opportunity to give up their itinerant way of life and settle down. Although for several reasons these efforts did not bear fruit, for the moment it seems that the civilization offensive launched by enlightened authorities had somewhat subdued the tendency to equate criminals or wandering people with "gypsies" and therefore the category was not used as a generic term for all sorts of unwanted wandering people. Instead there was a predominance of more general terms as Gauner and Jauner, as was mentioned earlier.

\section{POLICE JOURNALS AND THE GROWING OBSESSION WITH «GYPSIES» (1830-1870)}

The activities of the criminalists resulted in a more systematic description of wanted or «dangerous» people. More cogently for our topic, attention shifted from bandits to a much broader category of people without a fixed abode, the so-called gemeinschädliche Umhertreiber (harmful tramps). The police journals, which appeared on a regular basis after 1820, taking over the function of the Actenmäßige Nachrichten, continued this trend.

The publication of the police journals in various German states was an important step in the professionalization of the police. Although initially it was a private initiative taken by police officers, the state took control after 1840 and turned these journals into official organs. An overview is given in the following diagram:

22 With an exception for Schäffer (1813) and Pfeiffer (1828).

23 Schäffer (1788, p. 13).

24 Schäffer (1813, p. 155). See for an extensive analysis of Grellmann's work, especially the influence of the Enlightenment, Willems (1995 and 1997). 
Figure 1: German Police Journals (1802-1920)

\begin{tabular}{|c|c|c|}
\hline Title & Years & Distribution \\
\hline $\begin{array}{l}\text { [Allgemeine] Deutsche Justiz-, } \\
\text { [Kameral-] und Policeifama }\end{array}$ & $\begin{array}{l}1802-1807 \\
1817-18271829\end{array}$ & $\begin{array}{l}\text { Austria, Bavaria, } \\
\text { Schwaben, Franken }\end{array}$ \\
\hline $\begin{array}{l}\text { Mittheilungen zur Beförderung } \\
\text { der Sicherheitspflege } \\
\text { [ab } 1855 \text { Königlich Preussisches } \\
\text { Central-Polizei-Blatt] }\end{array}$ & $1819-1854$ & $\begin{array}{l}\text { Prussia, but also } \\
\text { Bavaria, Saxony, } \\
\text { Hannover, Kurhessen, } \\
\text { Hessen-Darmstadt, } \\
\text { Hessen-Homburg } \\
\text { and Holstein }\end{array}$ \\
\hline $\begin{array}{l}\text { Allgemeiner Polizey-Anzeiger } \\
\text { für Thüringen, } \\
\text { Franken und Sachsen }\end{array}$ & $1835-1920$ & $\begin{array}{l}\text { Thüringian States, } \\
\text { Franken and Sachsen }\end{array}$ \\
\hline $\begin{array}{l}\text { Der Wächter: Zeitschrift fur } \\
\text { Polizeiwissenschaften } \\
\text { u. Polizeipraxis } \\
\text { [ab } 1840 \text { 'Polizeianzeiger } \\
\text { für Norddeutschland'] }\end{array}$ & $1838-1933^{25}$ & $\begin{array}{l}\text { Grand Duchy } \\
\text { Mecklenburg, and } \\
\text { other parts } \\
\text { of Northern Germany } \\
\text { (Prussia, Hannover } \\
\text { and Holstein) }\end{array}$ \\
\hline $\begin{array}{l}\text { Fahndungsblatt } \\
\text { für das großherzoglich } \\
\text { badensche Corps-Commando } \\
\text { der Gensd'armerie }\end{array}$ & $1838-1876$ & Baden \\
\hline Hannoversches Polizeiblatt & $1846-1870$ & Kingdom Hannover \\
\hline $\begin{array}{l}\text { Königlich Preussisches } \\
\text { Central-Polizei-Blatt }\end{array}$ & $1855-1872$ & Prussia \\
\hline $\begin{array}{l}\text { Bayerisches } \\
\text { Central-Polizei-Blatt }\end{array}$ & $1866-1910$ & Bavaria \\
\hline
\end{tabular}

Source: Lucassen (1996, p. 232)

The analysis of these journals shows that, as we have already remarked, in the first place the police was interested in what they called harmful tramps (gemeinschädliche Umhertreiber). Contrary to what might perhaps be assumed, this referred not so much to itinerant groups such as wandering beggars, musicians, conjurers, acrobats, tinkers, scissors-grinders and peddlers, as first and foremost to labourers, especially travelling journeymen. With other workers, servants, and professions in what we nowadays call the service sector (waiters, hairdresser for instance) they make up three-quarters of all descriptions $\mathrm{s}^{26}$. This picture contradicts the widely held image (among both contemporaries and present-day historians) that people with itinerant professions formed the prototype of the Gauner ${ }^{27}$.

25 Only the years $1835-1868$ have been analyzed.

26

Based on a sample from the first half year of 1852 in the Allgemeiner Polizey Anzeiger.

27

See f.e. Egmond (1993). 
Maybe even more important than the distribution of occupations are the reasons why these people were wanted by the police. First of all only $18 \%$ was suspected of what was a more or less serious offence (several thefts and serious fraud). Apart from these «professionals», many people were wanted for petty theft and the like. More than $50 \%$ is simply listed because of minor offences such as begging, vagrancy, no clear means of identity, and so forth.

In themselves these conclusions are not sensational. Other scholars have noted that in the nineteenth century the police was primarily concerned with the classes dangereuses and with what they called vagrant ${ }^{28}$. Likewise, the fact that thefts were common at this time of wide-spread poverty is not new either ${ }^{29}$. Nevertheless, it is useful, indeed necessary, to stress these insights again, because many researchers easily allow themselves to be carried away by the contemporary one-sided stereotyping of the «criminal vagrant class $»^{30}$. Another important point is that it is seldomly recognized that the police was very much preoccupied with checking identity and (closely connected) with the increasing control of migration ${ }^{31}$. Both phenomena gained importance in the course of the nineteenth century in the wake of state formation which required an increased monitoring of citizens. People without a clearly fixed abode and without - in the eyes of the police - sufficient means of support were easily criminalized as Gauner.

Especially people entirely without or in the possession of dubious passports or identity papers were thought to be highly suspect. From a criminalist point of view this is partly understandable, as many criminals of course wanted to conceal their real identity. But, pertinent thought as it is, it is not the only reason. One of the other reasons is linked to the legislation concerning the poor relief system. Most German states adhered to the principle that each citizen had the right to settle in a municipality or to return to it after a period of absence. This so-called Heimatrecht also accorded the right to some form of poor relief ${ }^{32}$. The municipal police therefore tried to turn away strangers without a claim to their Heimat, which was only possible to establish when they could show where they belonged. As many itinerants were dependent on ambulant professions, and as these kinds of professions were (partly unjustly $)^{33}$ held in low esteem and considered to be a cloak of begging, many of these itinerants often concealed their identity. In such cases the police restricted themselves to taking them to the neighbouring municipality instead of sending them «home». Even when the police knew where their real Heimat was, they often did not have the power to force them to return there.

\section{GYPSY LABELLNG}

In contrast to the rise of the criminalists some fourty years earlier the police journals did affect the labelling of people as «gypsies» significantly. This is imme-

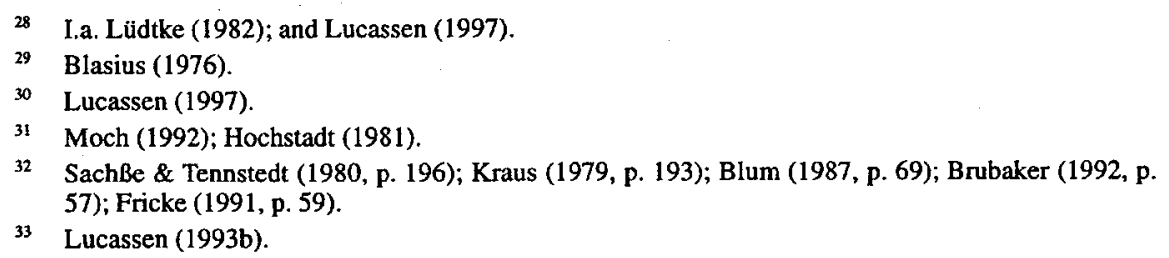


diately apparent when we take a look at one of the first official journals, the Hannoversches Polizeiblatt, issued by the royal government, which is representative of other journals.

Notwithstanding the often heard opinion that before the unification of Germany there were virtually no gypsies in the region and that official policy towards this category only became relevant after $1870^{34}$, a careful analysis of the hundreds of thousands descriptions between 1846 and 1870 offers quite a different picture. Long before 1870 the term Zigeuner had become dominant and the police started to use it to label all sorts of itinerant families who at an earlier stage had been invisible as such. From the start, 1846, Zigeuner was used as an important category to classify wandering people. The second issue already offered an extensive survey of the families Trollmann and Schwarz, who attracted attention because they were not Hanoverian citizens and were not equipped with the requisite permits to perform their itinerant professions ${ }^{35}$. This description formed the prelude to a much longer article on «gypsies» a year later ${ }^{36}$. The anonymous author claims that it is wrong to think that gypsies had disappeared from Germany. They had only split up their large companies and tried to conceal their true nature and identity. Therefore, so he goes on, it was of the utmost importance that the police draw up genealogical trees in order to discover their real Heimat and thus force them to adopt a sedentary lifestyle. This advice was taken to heart, because in 1847 such pedigrees were published for the «gypsy» families Brase, Weiss, Trollmann, and Tewitz ${ }^{37}$, completed in the years 1851-1853 by the families Hanstein, Steinbach, Bamberger, Wappler, and Mettbach $^{38}$.

1857 marked a important step forward in the labelling process. Until then the Trollmanns, Steinbachs and other families were scattered about among other wanted people in the container category «harmful tramps». In that year the editors decided to create a separate «gypsy» heading. At a glance the reader of the journal could now see who the gypsies were. The upshot was that the labelling was given greater priority and it became obvious to the readers (mainly lower-ranking policemen) that gypsies were an important category that had to be closely watched.

Why were some people labelled and others not? Travelling with one's family and carrying out an itinerant trade was not enough to ensure that one was designated and treated as a gypsy. The remarks in the Hannoversches Polizeiblatt, but also by no means absent in the other police journals, made it perfectly clear that policemen also had an, albeit vague, ethnic image of gypsies. A dark skin colour («a gypsy colour»), for example, is regularly mentioned. When we take a look at all the people who were labelled gypsies this feature is less obvious. There were also gypsies with fair skins and,conversely, dark itinerants who were not labelled. Criminal behaviour associated with gypsies, such as fraud and thefts, was not definitive either. Most gypsies

34 See e.g. Reinbeck (1861, p. 2 and p. 39); and Hehemann (1987), Strauss (1986), Günther (1985).

35 Hannoversches Polizeiblatt (1846, nos 10 en 11, p. 12-13). The same holds true for the «big gypsy family" Wappler (no. 1922 from juni 1847).

36 Hannoversches Polizeiblatt (November 1847, no. 3087, p. 1176-1183).

37 Hannoversches Polizeiblatt (1848, no. 3516, 3848, no. 4275, and no. 4315).

38 Hannoversches Polizeiblatt (1851, no. 10294; 1852, nos 13133 and $14366 ; 1853$, no. 15119). In 1856 the families Schwarzen (no. 27036) and Schmidt (no. 26394) followed. 
found their way on to the lists because their identity was vague or simply because they followed a travelling way of life. So, although a particular ethnic gypsy image certainly existed, in practice the application of it proved to be complicated. What is important is that a number of families was traced, their pedigrees researched thus marking them as gypsies, and that this information was widely disseminated among German police circles. As we shall see in the last section of this paper, this growing genealogical «database» formed the basis for the persecution of gypsies in the twentieth century.

Another reason to be sceptical of a purely ethnological explanation for the labelling of certain families as gypsies can be linked to the causes for the sudden upsurge in the labelling process. Although at a first glance this seems to be connected with the immigration of strange-looking families from both the Alsace and Eastern Europe, in most descriptions this in fact played no role. Far important to the categorization was the wandering way of life, the lack of clarity about their Heimat, and last but not least the besetting fear gripping the local authorities that these people would lay claim to their poor relief. This in itself, is not enough to explain why the police were ever more willing to apply the gypsy label to mark such people. In order to understand the modification of the labelling around 1840, the factors mentioned should be supplemented by two other developments:

1) First of all, Willem's research has unequivocally shown that it is important to realize that the very influential book by Grellmann on «the gypsies», which offered the first detailed «ethnographic blueprint», laid the conceptual foundation for both the categorization of and the idea that there was such a thing as a gypsy race or people ${ }^{39}$. The conceptual change in the idea of gypsies can be considered to be a necessary, but was by no means sufficient condition for the stepping up of the labelling. Moreover, it was temporarily moderated by the ideology of the enlightenment by which Grellmann was strongly influenced ${ }^{40}$.

After the failure of various gypsy colonies in Germany the (enlightened) optimism about the possibility of turning gypsies into decent citizens was replaced by the conviction that the «gypsy race» was incorrigible and was afflicted by a hereditary inclination to wander ${ }^{4}$. An idea that we also find recurring in the various articles on gypsies in the German police journals ${ }^{42}$.

2) Equally important in the pursuit of categorization seem to have been the general institutional changes within the police force itself and in its organisation. Especially the growing preoccupation of the police with wandering people and the proactive policy of distributing descriptions through police journals triggered off the «take-off» of the labelling from roughly about 1840 . Within the broad category of «harmful tramps», these people with unclear family relations created a need for a separate labelling. Many descriptions refer to the inextricable relationships between gypsies, deploring the many aliases and false identity papers

\footnotetext{
39 Willems (1995, p. 288-291).

40 Willems (1995, p. 23 ff.).

41 Willems (1995).

42 See for example Der Wächter, $\mathrm{n}^{05} 44-51,54-59,64,74,87$ and 90.
} 
they produced. Although it is not a simple matter to ascertain whether this phenomenon reared its head more frequently among «gypsies» than among others, a connection with an itinerant way of life is conceivable. As we mentioned earlier, many travellers had to use false papers to prevent being sent back to their Heimat. Were the authorities to notice this, they were arrested. The unravelling of the family relationships took so much time that they were left alone, simply being expelled from the municipality. My own strong impression is that especially these people who travelled with their families and posed grave identification problems to the police ran a fairly high risk of being labelled gypsies.

\section{A STRANGE INTERMEZZO (1870-1890)}

The administrative hunt for gypsies in which the police journals took the lead was not unilinear in the sense that as time went by progressively more and more people were thus labelled. In the 1860 s especially the interest in gypsies waned somewhat. This can be linked up with the developments within the German police. Here we see a whimsical growth of personnel and means. The work of Spencer and Jessen, for example, shows that the growth of the police force in the Prussian Ruhr area stagnated in the 1860 s and, measured against the number of policeman per 1,000 inhabitants shows several ups and downs. Only in the 1870 s can a considerable and final increase be noticed ${ }^{43}$.

At the same time, after the unification we see a paradoxical development. On the one hand the stigmatization by state authorities (through discriminating circulars) increased in most states ${ }^{44}$, while their definition was temporarily restricted to foreigners, a category which from then on meant people coming in from outside the German empire. The growing interest in the «gypsy problem» by people other than police authorities and the equation of gypsies with foreigners probably had its roots in the intense contemporary nationalistic fever and the strong feelings this engendered about the rights attached to citizenship ${ }^{45}$. The importance of the distinction between citizens and aliens, at the foundation of which lay the legislation on citizenship and the right to settle and receive poor relief in the $1860 \mathrm{~s}^{46}$, became more salient.

Above all people who came from abroad who might conceivably be expected to become a burden were considered undesirable. From 1865 when small familygroups of itinerant coppersmiths and bear-leaders from Hungary and Bosnia appeared $^{47}$, in next to no time the central level in various states issued circulars to keep these «gypsies» out ${ }^{48}$. As these higher-ranking officials assumed that gypsies were

43 Jessen (1991, p. 63); and Spencer (1992, p. 50, 52 and 166).

44 See Hehemann (1987).

45 This fear for the fragile national identity was primarily aimed at the Polish-speaking minority in the eastern part of the country (Herbert, 1990, p. 10-11).

46 In Baden in 1862, in Bavaria in 1868 (Hehemann, 1987, p. 278). See also Brubaker (1992). Prussia was the first state with its act in 1842 .

47 See Lucassen and Willems (1995).

48 In Prussia 22-10-1870, in Saxony 17-12-1870, the North-German Bund 12-12-1870, in Bavaria 121-1871, in Hessen 15-5-1871 and in Baden 19-9-1872 (Hehemann, 1987, p. 245, 323, 277; Strauss, 1986, p. 33; Höhne, 1929, p. 187; and Fricke 1991, p. 90). 
per definition foreigners, they thought these measures were sufficient to meet their purpose.

This focus on foreigners adopted by the central authorities was not to last long, and by the early 1880 s the indigenous definition which had been in the police journals since 1840 was already proving too strong an undercurrent. We are especially well-informed about the southern states. An 1880 letter from the Palatine district region to the district authorities illustrates the trouble that the rank-and-file police had with the restriction of the gypsy label to aliens:

Eigentliche Zigeunerbanden, d.h. umherziehende Ausländer [...] wurden in lezter Zeit im diesseitigen Bezirke überhaupt nicht betreten [...] Dagegen wurden in letzter Zeit zigeunerartige Banden hieramts angezeigt, welche man, da deren Mitglieder preußische Staatsangehorige waren, auch nach Preußen transportieren lie $\beta^{49}$.

Finally, the continuity in the labelling of indigenous travellers can be seen in the Bayerisches Central-Polizei-Blatt, which first appeared in Bavaria in 1866. Only a small proportion of the people labelled as gypsies came from non-German states ${ }^{50}$. The others had German names and had been born in Germany or adjoining French regions. In contrast to the Netherlands, the term «gypsy» was not reserved for the new immigrant groups from Eastern Europe. It was predominantly the group of indigenous travellers which were increasingly confronted with this label. This development can be traced to the labelling practice pursued in the police journals and, after 1885 , it would lead to a strong focus on gypsies as an «internal problem». Before we go deeper into that matter, let us once more return to the more general developments in the police force.

\section{SPECIALIZATION OF THE POLICE FORCE AND THE SETTING UP OF A GYPSY REGISTRATION (1890-1918)}

The last decade of the nineteenth century marked an important phase in the development of the German police. More policemen were recruited, but what is even more relevant they were better trained and the police forces became more speciali$z^{5} d^{51}$. At the same time, as the German historian Ralph Jessen has shown in a recent paper, especially between 1870 and the end of the nineteenth century, the Prussian police attracted more and more welfare tasks. As a result the power of the police to label all kind of behaviour as deviant and undesirable increased. This «full authority to act ${ }^{52}$ showed itself among other manifestations in the social domain. Alcohol consumption, unhygienic housing, suspect mobility and other social ills were considered to be problems pertaining to the sphere of Ordnung und Sittlichkeit.

49 Strauss (1986, p. 33).

so Sample from the years $1866,1870,1975,1880,1885$ and 1890 . From the 39 descriptions of groups of gypsies only 6 came from Austria, Hungary, Bohemia, and Croatia.

si Becker (1992, p. 126-127); Spencer (1986 and 1992); Funk (1993); Regener (1992); Diembach and Roth (1993); and Roth (1994).

s2 Jessen (1994, p. 161). 
The «unlimited administrative definitory power» ${ }^{53}$ of the police was the result of the mounting intervention of the state which had been growing since the 1870 s. Although the police definition also had all kinds of positive effects, this certainly was not always so, as Jessen remarks:
Problematischer ist sicherlich der Interventionsbereich, in dem sich die Zuständigkeit der Polizei nicht aus deren Wohlfahrtsaufgaben, sondern aus ihrem Ordnungsauftrag herleitete. In dieser kritischen Zone schlugen klassenspezi- fische Werte ziemlich ungefiltert auf die "erzieherische Mission" der Polizei durch. Der repressive Zugriff war hier nicht nur inadäquat, weil er die Ursachen der Probleme nicht erfaßte, sondern auch hochgradig parteilich, weil er bürger- liche Verhaltensmuster als allgemeinverbindlich festschrieb $b^{\text {s4 }}$.

This conclusion helps us to put the gypsy policy that emerged at the end of the nineteenth century into its proper context, for it remained entirely within the Sicherheitspolizeiliche domain, with the result that the definitory as well as the discretionary power of the police was scarcely subjected to any checks at all. Whereas after c. 1890 in many welfare domains the police grew more careful about offending citizens too much and therefore not penalizing every offence, the gypsy policy went in the opposite direction. The police used every rule and regulation to make matters as difficult as possible for travelling groups, with all the criminalizing effects that were part and parcel of such a move.

The consequences of these general changes in the police organization of the gypsy policy can be best illustrated by the activities of the Munich police. In 1899 this force decided to create a «Gypsy Information Service» with the aim of gathering as much data as possible on gypsies (place and date of birth, profession, whereabouts, offenses and so forth), so that the acts and regulations directed against them could be carried out more efficiently. The local authorities, including the gendarmerie, were ordered to forward all relevant data, preferably by telephone or telegraph ${ }^{55}$.

Alfred Dillmann was appointed head of the Zigeunerzentrale (Gypsy station), as it was soon to be called. For some time he had already been engaged in collecting data from gypsy families in Bavaria ${ }^{56}$. In doing so, he made extensive use of the Bavarian police journal mentioned earlier. In 1905 he collected his data together in the Zigeunerbuch (Gypsy Booklet), which contained some 3350 names and 613 extensive descriptions of people whom he labelled gypsies. This book (7000 copies), which was meant for official use only, is especially interesting because the author explicitly addresses the question of definition. In the introduction he clearly states that he uses «gypsies» as a sociological category: everyone who travels around with his or her family, irrespective of ethnicity or nationality. Within this broad category he made a distinction between «gypsies» (440 persons) and «people who live like gypsies» (173 persons). When we analyse the 613 descriptions $^{57}$, we

53 Jessen (1994, p. 167).

54

Personalia, identification papers, number of caravans and horses, origin and travel direction, offences, measures taken against them and, if relevant, the reason why no action had been brought against them (Reich, 1927, p. 41-42).

Strauss (1986, p. 44).

Lucassen (1996, p. 255-256). 
find that persons whose personalia gave rise to some doubt had a bigger chance of being labelled a real gypsy than the others. In the tradition of the nineteenth century police journals, gypsies were primarily associated with people who tried to hide their real identity by giving false information about their names, place, and time of birth and the like. It is also striking that only a few foreign gypsies are listed and that ethnographic features, such as skin colour or language played a subordinate role.

These people drew the attention of the police predominantly because of minor offenses which were closely linked to the travelling way of life, such as the very broadly defined concept of vagrancy, or offenses which were the direct result of the criminalizing gypsy policy ${ }^{58}$. It was not so much criminality which caused concern as the «disorderly» way of life. The police viewed gypsies as an annoying travesty of the legal system. This might explain the sometimes utterly unrealistic proposals for putting an end to the supposed danger that gypsies posed to public safety and order. In this respect, the plan the policeman Franz Laufer proposed in the Polizeibeamtenblatt of 1912, for the creation of a special gypsy police force in order to enable a constant surveillance system to be introduced, is noteworthy ${ }^{59}$.

It was around about this same time, the Munich gypsy station tried to expand its activities over the rest of Germany. Other states reacted reluctantly to this proposal, especially Prussia, because of the costs it would involve. Further there were disagreements about the definition of gypsies. Many states opposed Dillmann's broad sociological definition because they feared that all kind of edecent» itinerant traders and artisans would also be hurt. In the end, agreement was reached on basis of Dillmann's ideas:

Zigeuner im polizeilichen Sinne sind sowohl die Zigeuner im Sinne der Rassenkunde als auch die nach Zigeunerart umherziehenden Personen ${ }^{60}$.

Despite this, there was still a long way to go to reach an efficient mutual agreement. After World War I the Bavarian Gypsy Station tried with renewed vigour to achieve its purpose and monopolize the gathering of data on gypsies for the whole of Germany.

\section{THE WEIMAR PERIOD (1918-1933)}

The Weimar Period is of interest because then the police tried to put the distinction between "gypsies» and «people living like gypsies», the latter being labelled as Landfahrer (travellers), and honest itinerants into practice. The former had to be treated with the utmost severity, using such tactics as refusing them permits to travel and perform itinerant trades, whereas the second would be protected. This proved to be far from easy. The problem, and here we touch the very heart of the problem addressed in this paper, were the following assumptions:

1) It is possible to distinguish «real gypsies» from others on the basis of racist and ethnological criteria;

2) Gypsies are per definition parasites and their occupations serve as a cloak for begging, vagrancy, and ultimately crime.

SB Lucassen (1996, p. 255-256).

59 Hehemann (1987, p. 231-233).

60 Strauss (1986, p. 68). 
Not only were local authorities unable to see the difference between «real» gypsies and other caravan dwellers, the art of being able to distinguish honest from dishonest itinerants was far from clear cut. Therefore most acts and regulations geared towards a differentiated policy for all itinerant groups failed.

The insuperable contradictions that characterized the Bekämpfung des Zigeunerunwesens can be best illustrated by the preparation of the Bavarian act against gypsies and the workshy of $1926^{61}$. First of all, organizations of itinerant peddlers and showmen ${ }^{62}$, who supported the act in itself and thereby strengthened the assumptions mentioned above, complained about the deleterious effects, for it appeared that notwithstanding the protection that the act offered to «honest itinerants» by means of a Schutzvermerk $k^{63}$, many of their members were lumped together with other itinerants and confronted by the same severe surveillance and controls. The problem was exacerbated as there were quite a few such members who did not have a fixed abode and therefore were unable to obtain a Schutzvermerk. The boundary between Landfahrer and Zigeuner on the one hand and «decent itinerants" on the other was not an ethnic one. The decisive factor was the way of life. Everyone with a fixed abode was excepted from the stipulations of the 1926 Act. Apparently it was assumed that gypsies could never meet these criteria.

In view of the foregoing, it is not surprising to discover that the central police station in Munich was dissatisfied with the Schutzvermerk policy. They thought that the authorities both local and regional were far too tolerant and flippant, because they forgot to contact it first in order to verify if an itinerant applicant was to be classified as a Zigeuner or Landfahrer. The 1926 Act was meant to put an end to these abuses, was the way the Munich police interpreted it. A distinction between gypsies and other tramps and honest itinerants was made, and what is more for the first time gypsies were defined in racial terms:

Das fahrende Volk der Zigeuner ist seit dem 15. Jahrhundert, in dem es zum ersten Mal in Deutschland aufgetreten ist, ein schädlicher Fremdkörper in der deutschen Kultur geblieben. Alle Versuche, die Zigeuner an die Scholle zu fesseln und an eine sesshafte Lebensweise zu gewöhnen, sind fehlgeschlagen. Auch drakonische Strafen konnten sie von ihrer unsteten Lebensführung und ihrem hange zu unrechtmässigen Vermögenserwerb nicht abbringen. Trotz vielfacher Vermischungen sind ihre Abkömlinge wieder Zigeuner geworden mit den gleichen Eigenschaften und Lebensgewohnheiten, die schon ihre Vorfahren besessen hatten. $Z u$ diesen Rassezigeunem gesellten sich mit der Zeit noch die sogenannten Inlandszigeuner, das sind Inländer, die die Lebensweise der Zigeuner angenommen haben und dadurch in gleichem Masse wie diese lästig fallen ${ }^{64}$.

Apart from the «racial gypsies» the act referred to the people who lived like gypsies, and who were by definition even more destable. The provisions of the act made it possible to lock up these categories in workhouses solely on the basis of vague and

\footnotetext{
61 Reich (1927).
}

62 Among them being the Süddeutscher Verein reisender Schausteller und Handelsleute from Nürnberg and the Reichsverband ambulanter Gewerbetreibenden (Lucassen, 1996, chapter 5).

63 Their licence to perform an itinerant profession was amplified with a special Schutzvermerk (protective notice).

64 Proposal for the 1926 Act: Bayerische Landtag, III Tagung 1925/26. Beilage 1970, Staatsministarium des Innem to the Präsidenten des bayerischen Landtags, 12-3-1926 (Hauptstaatsarchiv München, Mwi, 839). 
subjective judgements. Thus, the Bavarian act against «gypsies and the workshy» preceded the nazi regulations a decade later.

It is perhaps superfluous to say that this act resolved neither the definitory nor the policy problems mentioned above. Again it was left to the discretion of the local authorities to make a distinction between the various categories. Moreover, the act characterized by contemporaries as reactionary and reeking of a police state ${ }^{65}$ - chopped of its nose to spite its face, because it failed to forbid the issuing of permits to Zigeuner and Landfahrer. Until far in the 1930s complaints could be heard about gypsies with licences and a Schutzvermerk. An effective policing as envisaged by the police was thus frustrated.

\section{WHAT'S NEW ABOUT THE NAZIS? ${ }^{66}$}

In the years following the 1926 Act other German states followed the example of Bavaria. Thereby the foundation of the Nazi policy was firmly laid. We might therefore ask ourselves to what extent the Nazis added a new dimension to the policy adopted towards gypsies after 1933 and how important the weight of the police tradition was.

As we have seen the activities of the police journals in the mid nineteenth century for the first time transformed the category Zigeuner into a master status; a (negative) category so dominant that it eclipsed all other features of a person who was thus labelled. This practice was intensified by the specialization of the Munich police, which continued the practice developed by the police journals half a century earlier. By this time the sensitivity towards the term had increased greatly and a growing number of people had been labelled as such. The 3350 personal files compiled by Dillmann in 1905, among which were those of many Zigeuner from other states, increased to 33524 in 1938, the moment that Munich was recognized as the national centre of intelligence ${ }^{67}$. This increase can be explained only partly by normal demographic causes or by the extension of the Bavarian registration practice over the rest of Germany. Another important cause of the rise in numbers was the application of the gypsy label to the Nach Zigeunerart umherziehende Personen (people living like gypsies) ${ }^{68}$.

Only after 1933, when the Nazi engulfed the constitutional state, were the police really given the chance to control the mobility of itinerant groups. Unhindered by democratic checks or constitutional objections, the Munich centre took the lead in dealing for good and all with the "gypsy problem», as it was called. The increased power given to the police, who worked hand in glove with other

65 D. Karanikas, cited by Strauss (1986, p. 84).

66 I will not treat this period in full, but select only those developments which are of direct relevance to my main question. For a more thorough overall analysis see: Ayass i.a. (1988); Zimmermann (1989, 1992, and 1996); Eiber (1993); Riechert (1995); and Willems (1995).

67 Eiber (1993, p. 51). Of these 33,524, 18,138 were classified as «gypsies», 10,788 as «people living like gypsies» and 4,598 «other travellers». Note that the 3,350 persons published by Dillmann also consisted of these categories.

68 In 1905 the «people living like gypsies» made up 28\% of Dilmann's 613 full descriptions. In 1938 this has risen to some $38 \%$ and if we include the «other travellers» in the equation its share increases to $43 \%$. 
authorities, is uncompromisingly revealed in the construction of guarded camps in a number of big cities ${ }^{69}$. At the same time, from 1933, the police locked up small numbers of gypsies, with other so-called anti-social people, in work-camps. From 1936 the concentrationcamps Dachau and Buchenwald were used for this very same purpose ${ }^{70}$.

As Zimmermann and others have shown ${ }^{71}$, during the Nazi era gypsies found themselves at the crossroad of deterministic ideas on anti-social behaviour and the racist doctrine. The police therefore was confronted with scholars and policy makers who began to take an interest in gypsies from these points of view.

This led to the question of whether gypsies were predominantly anti-social people, who had to be sterilized, or members of a separate race, who ultimately had to be killed. The answer, so it was thought, should not in the first instance come from the police, but from scholars specialized in hereditary problems. It is not surprising that a number of these academics seized their chance to dominate this new definitory terrain. In the case of gypsies the leading role was taken by the psychiatrist Robert Ritter $^{72}$, who was appointed as head of the Rassenhygienische Forschungsstelle ${ }^{73}$ of the Reichsgesundheitsamt in 1936. It was up to him to decide on a scientific basis who was a gypsy and who was not. Soon Ritter was appointed advisor to of the Reichskriminalpolizeiamt (RKPA), where the files of the Munich Gypsy Station were concentrated, because the head of the RKPA, Arthur Nebe, realized that although he had a highly detailed gypsy registration at his disposal, it had not been compiled primarily on racial grounds ${ }^{74}$.

Ritter's approach was not, as is often assumed, based on ethnological or anthropological methods ${ }^{75}$. No more than jews could be distinguished from «Aryans» on the basis of their hair, colour of their eyes, or shape of their noses, was there any clear phenetic line between gypsies and other Germans. This did not cause Ritter to reflect that perhaps his racial assumptions were flawed, on the contrary, he saw it as a proof for the far-reaching extent of mixing that had taken place in the past centuries. He tried to corroborate this idea by gathering as much genealogical data as possible, which formed the basis for the decision of who was classified as full-blood, mixed, or non-gypsy ${ }^{76}$.

How Ritter and his team operated is not entirely clear. The most probable scenario was that he based himself on the registration of gypsies by the police ${ }^{77}$ and then tried to trace these people back in time. Judging from the smallness of Ritter's staff and the number of gypsies (c. 25,000) that had to be «weighed», prudence cannot

69 Zimmermann (1989, p. 18-22); and Von Hase-Mihalik and Kreuzkamp (1990, p. 47).

70 Von Hase-Mihalik and Kreuzkamp (1990, p. 85).

11 Zimmermann (1989, 1992, 1996); Willems (1995) and Riechert (1995).

72 For an analysis of his work and activities see the innovative dissertation of Willems (1995, Chapter 5).

73 Also known as the Rassenhygienische und bevölkerungsbiologische Forschungsstelle (Zimmermann, 1989, p. 33).

74 Willems (1995, p. 257).

75 Willems (1995, p. 257-258).

76 See also Zimmermann (1989, p. 35).

77 In a letter d.d. 17-10-1939 from the Reichssicherheitshauptamt to the Staatliche Kriminalpolizei the local police and gendarmerie were ordered to make lists of all the «gypsies" and mixed-blood gypsies under their jurisdiction (Riechert, 1995, p. 105). 
have been their watchword ${ }^{78}$. In the few short months between December 1938 and April 1939 some 3000 Gutachten (reports on individual gypsies) were expected to be delivered ${ }^{79}$. Pausing to consider how time-consuming thorough genealogical research is, especially with travelling people, our conclusions must be most Gutachten were made on very dubious grounds. Scepticism about the reliability of Ritter's work mounts, when we remember that his institute benefited financially from the making out of Gutachten. The German historian Riechert even argued that this played a crucial role in the financing of his Rassengygienische Forschungsstelle $e^{80}$.

\section{CONCLUSION}

The gypsy persecution under the Third Reich provides an answer to the main question posed by this paper: whether there is any connection between the activities of the eighteenth century Kriminalisten and the persecution and stigmatization of gypsies and other travellers by the Nazis.

It is widely assumed that Ritter and his team were to blame for the mass murder of some 10,000 German gypsies in the concentration camps. He offered them as it were on a salver and, moreover, defined who was to be regarded as such. The «innovative" aspect of his racial-genealogical method would have included a new group of gypsies: those who had settled in houses and who were not gypsies in the traditional Dillmannian definition ${ }^{81}$. This view, ascribing a huge responsibility to Ritter and his team is in itself not unjustified, but it is unlikely that they played an initiating and innovative role, and - as Zimmermann writes - his institute:

[...] im Laufe ihrer Suchtätigkeit mehr als 19.000 *Zigeuner» und «Zigeunermischlinge» und sonstige Landfahrer im «Altreich» entdeckte (my emphasis, LL) ${ }^{82}$.

If we take the activities of the Munich Gypsy Station, which in practice functioned as a national centre after 1931, into account we see that in 1938, when Ritter started his research, some 18,000 files had already been assembled, dealing with a total of 33,524 persons. Of them the Reichszentrale zur Bekämpfung des Zigeunerunwesens labelled 18,138 Zigeuner and Zigeunermischlinge, 10,788 nach Zigeunerart umherziehend and 4,598 sonstige umherziehende oder auch seßhafte Wandergewerbetreibende ${ }^{83}$. Ritter's stock-taking two years later barely deviates from this categorization. Although we are not sure if Ritter had the same persons in mind, it is highly probable that he just took over the definition offered by the police registration and provided it with a «scientific» stamp. Even the genealogical method was already widely used by the police after $1913^{84}$. Finally it would seem

78 See also Willems (1995, p. 266-271).

79 Willems (1995, p. 265).

80 For every Gutachten he received 5 Marks. One of his employees, Würth- declared after the war: «B̈̈ndelweise habe er sie ohne hinzuschauen unterschrieben und räumt ein, daß sie sogar Gutachten über Tote fabriziert hätten» (Riechert, 1995, p. 17).

${ }^{81}$ Eiber (1993, p. 99-111).

82 Zimmermann $(1989$, p. 36).

83 See also Willems (1995, p. 264) on the close connections between Ritter's institute and the national centre.

Von Merz (1927, p. 4). 
that the police also had started gathering data on sedentary gypsies before Ritter began his research.

This reconstruction shows that in many aspects the Nazi period just continued the traditional labelling of gypsies by the German police. The «only» significant change was the means it was offered by the dictatorial and terrorist regime and the extermination policy. The Munich Gypsy Station especially seemed to be much more important in deciding who was a gypsy than was Ritter's racial institute. As a matter of fact, the distinction made by Dillmann between Zigeuner and nach Zigeunerart umherziehende Personen was what laid the foundations for the racial classification used later. But not even Dillmann worked in a void. As we have seen his approach and methods lean heavily on the police practices which were developed at the end of the eighteenth and which were given extra impetus by publication of the police journals in the nineteenth century.

This brings us to the specific contribution of this paper to the history of the police in Germany. The most important of these is the light it sheds on the early beginnings of the professionalization of the police. In 1984 Siemann already pointed to the importance of the police journals ${ }^{85}$, stressing their preventive and proactive functions and their stimulating influence on a more structural co-operation by means of data exchange. This paper gives added support to his provisional suggestions and moreover shows that a systematic and proactive approach to the tracing of criminal or unwanted persons had already started in the eighteenth century with the issuing of Steckbriefe. The authors, the Kriminalisten, can be considered the link between indirect and direct rule, or - from a different angle - between reactive and proactive policing ${ }^{86}$.

The most striking aspect of the tracing is the continuity in the target groups and methods used. In the eighteenth as well as in the twentieth century policemen were primarily interested in obtaining a better insight into the real and the potential criminals (broadly defined), and thus curbing the danger that these persons posed to the public. One of the consequences was the formation of certain categories, such as vagrants, gypsies, jews, journeymen, prostitutes, and during the Nazi period «antisocial enemies», who were thus problematized and then stigmatized.

Finally this paper has dealt with the labelling of gypsies. Notwithstanding the multitude of studies on the persecution of gypsies in Germany that have been undertaken in the last fifteen years, the problem of the labelling has barely been touched by most researchers. This oversight can be explained by the implicit assumption that historical sources pose no problem about the question of who is a gypsy. An assumption that is re-inforced by the use of the ethnic term Sinti und Roma instead of gypsies. This habit springs not such much from historical considerations, but is the fruit of the actual political (correct) struggle of interest groups from among and for gypsies.

From a scholarly point of view, the biggest disadvantage of the Sinti und Roma approach is that all kinds of contemporary racist as well as present-day ethnic categories are thus used. As this paper has tried to show, this easily leads to anachronis-

85 Siemann (1983, p. 76).

86 For these concepts see Tilly (1990, p. 107). 
tic and unjustified interpretations. Assuming that there ever was a clearly ethnically defined Sinti und Roma group in the past means that we in fact accept the point of departure (not the enforcement and consequences) of Ritter and his team, namely that it was possible to define who was a «real» gypsy.

In this respect it would be interesting to research the question of to what extent the atrocities committed against gypsies during the Nazi regime - but also in the period before - did stimulate the group formation and ethnicity. What was the relationship between labelling and ethnicity? Did they always regard themselves as «Sinti» or «Rom» or was this feeling re-inforced or even initiated by a long period of intensive stigmatization and labelling ${ }^{87}$.

\section{EPILOGUE}

In 1945 the entire registration of the Munich Zentral was destroyed, it seems. In 1954 the Bavarian police took up the thread again and erected a Landfahrerzentrale, building up among other files a new registration system of travellers and gypsies, based on the Bavarian Act of $1926^{88}$. Only in 1970 was this Sonderbehandlung closed after protests by pressure groups, although grave doubts may be cast on whether the police really changed their practice after that date ${ }^{89}$. The genealogical material gathered by Ritter and his team made a series of strange and mysterious detours, to end up only in part in the general archive of Koblenz. Since then several researchers have used it in order to continue Ritter's (he died in 1951) approach.

\section{REFERENCES}

Ayass, W. et al., Feinderklärung und Prävention. Kriminalbiologie, Zigeunerforschung und Asozialenpolitik, Berlin, 1988.

Bader, K. S., Kriminelles Vagantentum im Bodenseegebiet um 1800. Zu einer Jaunerliste des Reichenauer Obervogts Friedrich v. Hundbiss aus dem Jahre 1804, Schweizerische Zeitschrift für Strafrecht, 1962, 78, p. 291-333.

Becker, P., Vom «Haltlosen» zur «Bestie». Das polizeiliche Bild des «Verbrechers» im 19. Jahrhundert, in Lüdtke, A., (ed.), «Sicherheit» und "Wohlfahrt». Polizei, Gesellschaft und Herrschaft im 19. und 20. Jahrhundert, Frankfurt am Main, 1992, p. 97-132.

Blasius, D., Bürgerliche Gesellschaft und Kriminalität. Zur Sozialgeschichte Preußens im Vormärz, Göttingen, 1976.

Blum, P., Staatliche Armenfiursorge im Herzogtum Nassau 1806-1866, Wiesbaden, 1987. Brubaker, R., Citizenship and nationhood in France and Germany, Cambridge, Mass./London, 1992

Burleigh, M., WippermannW., The Racial State. Germany 1933-1945, Cambridge, 1991.

Cottaar, A., Lucassen L., WillemsW., Justice or injustice? A survey of the policy towards gypsies and caravan dwellers in Western Europe in the 19th and 20th centuries, Immigrants and Minorities, 1992 (March), 11, 1, 42-66.

87 See also Lucassen (1995).

88 Winter (1988, p. 145); Cottaar i.a. (1992, p. 54-55); Willems (1995, p. 276-285).

89 Feuerhelm (1987, p. 117); Zimmermann (1992, p. 364-370). 
Danker, U., Räuberbanden im Alten Reich um 1700. Ein Beitrag zur Geschichte von Herrschaft und Kriminalität in der frühen Neuzeit, Frankfurt am Main, 1988.

Diembach, T., Roth A., Die Disziplinierung der Polizei im Kaiserreich. Das Verhältnis des Beamten zum Dienstherm und zur Bevölkerung in einer Umbruchphase, Die Polizei, 1993, 4, p. 92-98.

Dubler, A.-M., Armen- und Bettlerwesen in der gemeinen Herrschaft «Freie Ämter» (16. bis 18. Jahrhundert), Basel, 1970.

Eiber, L., (ed.), «Ich wußte, es wird schlimm.» Die Verfolgung der Sinti und Roma in München 1933-1945, München, 1993.

Egmond, F., Underworlds. Organized Crime in the Netherlands 1650-1800, Oxford, 1993.

Feuerhelm, W., Polizei und «Zigeuner». Strategien, Handlungsmuster und Alltagstheorien im polizeilichen Umgang mit Sinti und Roma, Stuttgart, 1987.

Finzsch, N., Räuber und Gendarme im Rheinland: das Bandenwesen in den vier theinischen Départements vor und während der Zeit der französischen Verwaltung (1794-1814), Francia, 1987, 15, p. 435-471.

Finzsch, N., Obrigkeit und Unterschichten. Zur Geschichte der rheinischen Unterschichten gegen Ende des 18. und zu Beginn des 19. Jahrhunderts, Stuttgart, 1990.

Fricke, T., Zwischen Erziehung und Ausgrenzung. Zur württembergischen Geschichte der Sinti und Roma im 19. Jahrhundert, Frankfurt am Main, 1991.

Funk, A., Polizei und Rechtsstaat. Die Entwicklung des staatlichen Gewaltmonopols in Preußen 1848-1914, Frankfurt, 1986.

Funk, A., Die Entstehung der modernen Polizei in Preussen, 1870-1890. Bezugspunkte einer historischen Polizeianalyse, in Reinke, H., (ed.), «... nur für die Sicherheit da...?». Zur Geschichte der Polizei im 19. und 20. Jahrhundert, Frankfurt am M., 1993, p. 56-70.

Grellmann, H.M.G., Die Zigeuner. Ein historischer Versuch über die Lebensart und Verfassung, Sitten und Schicksale dieses Volks in Europa, nebst ihrem Ursprunge, Dessau/Leipzig, 1783, zweite Auflage 1787.

Günther, W., Die preußische Zigeunerpolitik seit 1871 im Widerspruch zwischen zentraler Planung und lokaler Durchführung, Hannover, 1985.

Hase-Mihalik, E. von, Kreuzkamp, D., Du kriegst auch einen schönen Wohnwagen. Zwangslager fur Sinti und Roma während des Nationalsozialismus in Frankfurt am Main, Frankfurt am Main, 1990.

Hehemann, R., Die «Bekämpfung des Zigeunerunwesens» im Wilhelminischen Deutschland und in der Weimarer Republik, 1871-1933, Frankfurt a.M., 1987.

Herbert, U., A History of Foreign Labor in Germany, 1880-1980, Ann Arbor, 1990.

Hochstadt, S., Migration and industrialization in Germany, 1815-1977, Social Science History, 1981, 5, 4, p. 445-468.

Höhne, W.-K., Die Vereinbarkeit der deutschen Zigeunergesetze und-verordnungen mit dem Reichsrecht, insbesondere der Reichsverfassung, Heidelberg, 1929.

Hundbiss-Waltrams, Fr. Freiherr von, Jaunerliste [...], Reichenau, 1804.

Jessen, R., Polizei im Industrierevier. Modernisierung und Herrschaftspraxis im westfälischen Ruhrgebiet 1848-1914, Göttingen, 1991.

Jessen, R., Polizei, Wohlfahrt und die Anfänge des modernen Sozialstaats in Preußen während des Kaiserreichs, Geschichte und Gesellschaft, 1994, 20, 2, p. 157-180.

Kastell, F. L. S. von, Oberdischinger Diebs-Liste [...J, Tübingen, 1799.

Kraus, A., «Antizipierter Ehesegen» im 19. Jahrhundert. Zur Beurteilung der Illegitimität unter sozialgeschichtlichen Aspekten, Vierteljahresschrift für Sozial- und Wirtschaftsgeschichte, 1979, 66, 2, p.174-215. 
Küther, C., Räuber und Gauner in Deutschland, Göttingen, 1976.

Lucassen, L., En men noemde hen zigeuners. De geschiedenis van Kaldarasch, Ursari, Lowara en Sinti in Nederland, 1750-1944, Amsterdam-Den Haag, 1990.

Lucassen, L., A blind spot: migratory and travelling groups in Western European historiography, International Review of Social History, 1993a, 2, p. 209-235.

Lucassen, L., Under the cloak of begging? Gypsy-occupations in Western-Europe in the 19th and 20th century', in Ethnologia Europaea. Journal of European Ethnology, 1993b, 23, p. 75-94.

Lucassen, L., Zigeuner in Deutschland 1870-1945: ein kritischer historiographischer Ansatz, 1999. Zeitschrift für Sozialgeschichte des 20. und 21. Jahrhunderts, 1995, 10, 1, p. 82100.

Lucassen, L., Willems, W., Wanderers or migrants? The movements of gypsies from Eastern to Western Europe (1860-1940), in Cohen, R., (ed.), The Cambridge Survey of World Migration, pp. 136-141, Cambridge, CUP, 1995.

Lucassen, L., Zigeuner. Die Geschichte eines polizeilichen Ordnungsbegriffes in Deutschland, 1700-1945, Köln-Wien, Böhlau Verlag,1996.

Lucassen, L., Eternal vagrants? State formation, migration and travelling groups in WesternEurope, 1350-1914., in Lucassen, J. and Lucassen, L., (eds.), Migrations, Migration History, History: Old Paradigms and New Perspectives, Bern etc..., 1997, p. 227-253.

Lüdtke, A., «Gemeinwohl», Polizei und «Festungspraxis». Staatliche Gewaltsamkeit und innere Verwaltung in Preußen, 1815-1850, Göttingen, 1982.

Lüdtke, A., Police and State in Prussia, 1815-1850, Cambridge, Paris, 1989.

Merz (von), Der kriminalpolizeiliche Charakter der Maßnahmen zur Bekämpfung der Zigeunerplage, Kriminalistische Monatshefte. Zeitschrift für die gesamte kriminalistische Wissenschaft und Praxis, 1927, 1, p. 3-7.

Moch, L. P., Moving Europeans. Migration in Western Europe since 1650, Bloomington, 1992.

Nitschke, P., Verbrechensbekämpfung und Verwaltung. Die Entstehung der Polizei in der Grafschaft Lippe, 1700-1814, Münster, 1990.

Pfeiffer, F.G., Stammtafeln mehrerer Gauner-Familien in der Provinz Niderhessen nebst einem Rundschreiben an die Kurfürstlichen Kreisräthe und die Fürstlichen Rothenburgischen Beamten, Cassel, 1828.

Regener, S., Verbrecherbilder. Fotoporträts der Polizei und Physiognomisierung des Kriminellen, Ethnologia Europaea, 1992, 22, 1, p. 67-85.

Reinbeck, E., Die Zigeuner, Salzkotten/Leipzig, 1861.

Reinke, H., (ed.), «...nur für die Sicherheit da...? . Zur Geschichte der Polizei im 19. und 20. Jahrhundert, Frankfurt am Main, 1993.

Reich, H., Das bayrische Zigeuner- und Arbeitsscheuengesetz vom 16. Juli 1926, München, 1927.

Riechert, H., Im Schatten von Auschwitz. Die nationalsozialistische Sterilisationspolitik gegenüber Sinti und Roma, Münster/New York, 1995.

Roth, A., Kriminalitätsbekämpfung in deutschen Großstädten 1850 bis 1914. Ein Beitrag zur Strafrechtsgeschichte anhand eines Vergleichs der Städte Berlin, Hamburg und Duisburg, Berlin, 1994.

Roth, F. A., General-Jauner-Liste [...], Karlsruhe, 1800.

Sachße, Chr., Tennstedt, F., Geschichte der Armenfürsorge in Deutschland vom Spätmittelalter bis zum 2. Weltkrieg, Stuttgart etc., 1980.

Schäffer, G. J. S., Zigeuner-Liste und genaue Beschreibung [...], Stuttgart, 1788. 
Schäffer, G.J.s., Beschreibung derjenigen Jauner, etc., Tübingen, 1813.

Siemann, W., Polizei in Deutschland im 19. Jahrhundert. Institutionen, Operationsebenen, Wirkungsmöglichkeiten. Mit neuen Dokumenten, in Schönert, J., (ed.), Literatur und Kriminalität. Die gesellschaftliche Erfahrung von Verbrechen und Strafverfolgung als Gegenstand des Erzählens. Deutschland, England und Frainkreich 1850-1880, Tübingen, 1983, p. 68-95.

Spencer, E. G., State power and local interests in Prussian cities: police in the Düsseldorf District, 1848-1914, Central European History, 1986, 19, 3, p. 293-313.

Spencer, E. G., Police and the Social Order in German Cities. The Düsseldorf District, 1848 1914, Dekalb, 1992.

Strauss, E., Die Zigeunerverfolgung in Bayern 1885-1926, Hausarbeit zur Erlangung des Magistergrades an der Ludwig-Maximilians-Universität zu München, 1986.

Tilly, C., Coercion, Capital, and European States A.D. 990-1990, Oxford, 1990.

Willems, W., Op zoek naar de ware zigeuner. Zigeuners als studieobject tijdens de Verlichting, de Romantiek en het Nazisme, Utrecht, 1995.

Willems, W., In Search of the True Gypsy. From Enlightenment to 'Final Solution', London, 1997.

Winter, M., Kontinuitäten in der deutschen Zigeunerforschung und Zigeunerpolitik, in Ayass, 1988, p. 135-152.

Zimmermann, M., Verfolgt, vertrieben, vernichtet. Die nationalsozialistische Vernichtungspolitik gegen Sinti und Roma, Essen, 1989.

Zimmermann, M., Ausgrenzung, Ermordung, Ausgrenzung. Normalität und ExzeB in der polizeilichen Zigeunerverfolgung in Deutschland 1870-1980, in Lüdtke, A., (ed.), Sicherheit und Wohlfahrt. Polizei, Gesellschaft und Herrschaft im 19. und 20. Jahrhundert, Frankfurt a/M, 1992, p. 344-370.

Zimmermann. M., Rassenutopie und Genozid. Die Nationalsozialistische «Lösung der Zigeunenfrage», Hamburg, 1996. 